\title{
Julia Gillard and the Gender Wars Linda Trimble
}

\section{University of Alberta}

$\mathrm{O}$ n October 9, 2012, Australian Prime Minister Julia Gillard delivered a powerful 15-minute speech to the House of Representatives, castigating her primary political opponent, opposition leader Tony Abbott, for his sexist and misogynist statements and behaviors, several of which had been directed at Gillard herself. The speech went viral. "Even as it was being delivered, Twitter lit up. Soon the blogosphere was aglow" (ABC 2012). Indeed, a YouTube (2012) clip of the prime minister's presentation in its entirety quickly gained more than a million hits. ${ }^{1}$ While her performance won praise from commentators in other parts of the world (e.g., Lester 2012), the Australian press gallery widely and vociferously condemned Gillard for "playing the gender card" and inciting “a gender war" (ABC 2012; Johnson 2015). Subsequent political strategies and public speech acts by the prime minister were also frequently characterized by the gender war metaphor.

The metaphor of the gender war rarely appears in news coverage of politics. Although aggressive sport and war metaphors are ubiquitous in mediated political discourses, women are typically positioned as the casualty, not the instigator, of these political battles. ${ }^{2}$ Notably, legal $^{2}$ restrictions on women's reproductive rights have been characterized as constituting a "war on women" (Faludi 1992), most recently as a "Republican war on women" (Melich 1996). The "war on women" metaphor casts women's bodies as the terrain on which strategic battles between Democrats and Republicans are fought. In this formulation,

1. As of February 26, 2016, the clip has been viewed more than 2.7 million times.

2. For example, Jonathan Kaufman and Carol Hymowitz, "At the Barricades in the Gender Wars: Clinton's Women Supporters Fear her Bid has Unleashed a Sexist Backlash," The Wall Street Journal, March 29, 2008.

Published by Cambridge University Press 1743-923X/16 \$30.00 for The Women and Politics Research Section of the American Political Science Association.

(C) The Women and Politics Research Section of the American Political Science Association, 2016 doi:10.1017/S1743923X16000155 
women are the objects whose bodies are governed by politics, not the agents of political decision making. In contrast, the Australian "gender wars" presented gender as the site of contestation and a powerful woman leader as the instrument of political "warfare." Julia Gillard's case represents a singular example of a government leader accused by pundits and opponents of deliberately initiating a series of destructive debates on the discursive battlefield of gender politics. As my analysis reveals, the metaphor exposed a number of assumptions about gender and power relations, particularly the role of gender in representations of the political. In Gillard's case, the gender war(s) metaphor fashioned discussions about gender and sexism as acts of extreme political violence. Moreover, Gillard and her party, the Australian Labor Party, were maligned for employing gender as both a subject and an apparatus of political contestation.

My goal in this paper is not to dissect the accuracy or validity of the media coverage or to "damask the 'untruth' of political metaphors" (Mottier 2008, 191), but rather to analyze the meanings revealed by the metaphoric constructions of Gillard and her party's actions as a series of destructive gender wars. Using critical metaphor and critical discourse analysis, I show that by configuring gender as a weapon of war, a defensive shield, or a site of political debate, the metaphor worked to emphasize certain perspectives on gender and political power while eliding others. In particular, the metaphor characterized Gillard's political tactics as a violation of deeply held cultural norms about appropriate behavior on the so-called political battlefield. I begin by discussing the importance of metaphors in mediated political discourses and summarizing the relevant literature on metaphoric constructions of politics and women politicians. After describing the texts analyzed for this study and the methods used to assess their meanings, I situate my analysis of the gender wars metaphor within its particular political context by sketching Gillard's political career and the gender politics associated with her leadership. I then relate the emergence and development of the gender wars metaphor, showing how the allegorical language of war and violence was used to support representations of Labor's political strategies in general, and Gillard's speeches in particular, as unusual and destructive political interventions. As a result, Gillard's experience presents a cautionary tale for women seeking elite leadership roles. The allegory of the gender war serves as a potent discursive tool that can be mobilized as a way of silencing and disciplining those who risk discussing sexism in political spaces or pointing out gender inequalities in access to political power. 


\section{THE LITERATURE ON METAPHORS AND GENDERED POWER RELATIONS}

Metaphors are important sites of investigation because of their ubiquity in political and media discourses, their powerful persuasive role, and their ability to reflect, reinforce, and sometimes contest gendered power relations. A metaphor is a seemingly straightforward rhetorical device whose essence is "understanding and experiencing one thing in terms of another" (Lakoff and Johnson 2003, 5). For instance, political leaders are fond of using journey metaphors, characterizing political action as movement toward a desirable destination (Charteris-Black 2011). In addition to evoking positive images of progress and greener pastures, journey metaphors render complex political goals and strategies intelligible by linking them to the tangible concept of travel. Indeed, a key function of metaphor is to facilitate comprehension (Lakoff and Johnson 2003, 10). Because metaphors draw upon taken-for-granted and seemingly common-sense understandings of everyday concepts, they "simplify abstract issues by activating preexisting knowledge" (CharterisBlack 2011, 34). For instance, when a politician is described as landing a metaphorical knockout punch on an opponent during a televised election debate, the audience is invited to understand the act of debating as a pitched battle between opponents.

Metaphors are not simply stylistic devices, or mere descriptions; they are powerful tools of persuasion (Koller and Semino 2009, 12), regularly deployed to punctuate political arguments and assert certain positions while delegitimizing others (Cammaerts 2012, 245). In fact, the primary use of metaphors in political rhetoric "is to frame how we view or understand political issues by eliminating alternative points of view" (Charteris-Black 2011, 32). When used as ideological devices, metaphors privilege and naturalize certain accounts by focusing attention on one aspect of the issue or event while diverting audiences from aspects that are inconsistent with the metaphor (Lakoff and Johnson 2003, 10). As the example of the "knockout punch" illustrates, by casting a political debate as an oratorical boxing ring in which fighters throw verbal punches at each other, the ideational, collaborative, and reflexive aspects of argumentation are concealed.

The metaphorical language of politics is largely communicated in and through the mass media. Indeed, as Castells $(1996,311)$ argues, the media extensively control the space in which politics happens. Despite the increased use of social media as sources of political information, 
television news and the online editions of established newspapers dominate the information cycle, providing key entry points into political debate (Neilsen and Schroder 2014, 473-74). Moreover, audiences tend to see the news, particularly TV news, as an objective source of "reality" (Falk 2013 , 194). But what audiences are seeing is a heavily mediated version of events, and metaphors are a common feature of this mediation process. Metaphors make stories about politics more vivid, dramatic, and entertaining (Gidengil and Everitt 1999, 41). As well, they act as a form of shorthand for journalists, helping to communicate abstract and complex ideas by presenting them in a simplified and accessible manner. Metaphors serve as "mini-narratives which are not fully explicated - the spelling out of the story is done by the audience which draws upon their tacit knowledge of the historical, social or political context to do so" (Mottier 2008, 191). Because they tap into social myths and popular understandings, metaphors reveal the cultural values resonant in the society within which media texts are produced and consumed (Falk 2013, 193; Gidengil and Everitt 1999, 51).

That war, violence, and aggressive sports metaphors are ubiquitous in media representations of politics is illustrated by a number of studies. As Blankenship's (1996) inventory of metaphors used to describe the 1972 U.S. Democratic party nomination demonstrates, metaphors referencing violence, warfare, and sports dominated news coverage of this event. Howe's (1988) analysis of political news coverage in U.S. newspapers and periodicals from 1980 to 1985 found the most commonly used metaphors were derived from the language of sports and war (e.g., "team player" and "guerrilla warfare"). Similarly, the 1984 U.S. presidential and vice presidential debates and party leaders' debates televised during the 2000 Canadian national election were cast as war zones, the contenders described as ambushing, firing at, and outflanking each other (Blankenship and Kang 1991, 308-309; Gidengil and Everitt 1999, 59). Lexical choices evoking conflict and violence have arguably become conventionalized in the political discourses communicated by the news media, with profound implications for the ways in which we understand politics and gendered relations of power.

Political women are often stereotyped and their performances delegitimized by the metaphors used to depict them (Ahrens 2009; Anderson and Sheeler 2005; Falk 2013; Lim 2009). Through battle metaphors, women's participation in political competition is framed by norms of hegemonic masculinity and patriarchal militarism (Koller 2004, 17-18; Lazar 2009, 210; Parry-Giles 2014, 187). The trope of the 
"unruly woman" is prevalent in the media's use of metaphors to portray women politicians because the specter of a woman behaving combatively disrupts normative expectations of female behavior (Anderson and Sheeler 2005, 28; Gidengil and Everitt 1999, 52). As a result, the anomalous position of women in elite business and political roles is highlighted by news reports drawing attention to and even exaggerating their belligerent behaviors through the use of war and aggressive sports metaphors (Gidengil and Everitt 1999, 60; Koller 2004, 13). For example, once Hillary Clinton "entered the spaces of electoral politics as a candidate, a rhetoric of violence became all too common in the press coverage" (Parry-Giles 2014, 185).

The news media consistently draw on predominantly male experiences and activities to define and describe political reality, thereby reinforcing gender-based power imbalances (Gidengil and Everitt 1999; Howe 1988; Koller and Semino 2009). Even seemingly benign metaphorical source domains, such as gaming, can have a damaging effect on women's political opportunities. As Falk's analysis of the U.S. news media's use of the playing-the-gender-card metaphor in reports about Hillary Clinton's 2008 bid for the Democratic presidential nomination revealed, the metaphor was used to "silence the idea that traditional sex roles affect who has access to power" (Falk 2013, 203). By implying that gender only becomes a factor in politics when women themselves raise it, the gender card metaphor occluded the reality of sexism and the unequal representation of women in political life (Falk 2013, 198). Yet the strategic use of metaphors by politicians or the media can also disrupt conventionally held assumptions about women and political leadership. For instance, by positioning women as full participants in the political "game" or "battlefield," combative metaphors suggest women politicians exercise both power and agency (Trimble and Treiberg 2010, 130). Regardless of whether they shore up hegemonic discourses or disrupt them, "gendered metaphors of power are not merely stylistic devices but foundational to the making and our understanding of political identities and realities" (Lim 2009, 258). The gender war metaphor speaks directly to the intersections of gender and power in political discourses.

\section{TEXTS AND METHODS}

Data for this study were drawn from uses of the gender war(s) metaphor in selected Australian newspapers throughout Gillard's term as prime 
minister, from June 23, 2010, when she assumed office, until June 26, 2013, when she was defeated in a leadership vote. Three leading Australian broadsheets, The Australian, The Sydney Morning Herald, and The Age were chosen for analysis because of their wide circulation in the most populated markets - Sydney and Melbourne - and across the country. The Australian newspaper industry is highly concentrated. By 2007 all but three papers were owned by three conglomerates, two of which, News Limited and Fairfax, controlled more than $90 \%$ of the newspaper circulation (Young 2011, 115). The Australian, the only newspaper with national distribution of its print edition, is owned by News Limited and is positioned on the ideological right. The Sydney Morning Herald (SMH) and The Age are Fairfax papers, distributed in Sydney and Melbourne respectively, and they tend to offer more centrist positions (Young 2011, 238).

An initial search of these newspapers with the Factiva database confirmed the prevalence of the gender war(s) metaphor in reporting about Julia Gillard, especially in reaction to her parliamentary speech on sexism and misogyny. The phrases "gender war" or "gender wars" appeared 97 times in 59 news articles printed over an eight and a half month period (September 15, 2012, to June 25, 2013), and the metaphor was featured in 12 headlines. One newspaper in particular was responsible for the introduction and persistent use of the metaphor. The Australian published 44 of the 59 articles featuring the gender war label (75\%), and printed 75 of the 97 discrete usages of the metaphor $(77 \%)$. All but four of the articles containing the gender wars metaphor were published after Gillard's socalled sexism and misogyny speech was delivered in Parliament on October 9, 2012, indicating that this speech triggered the widespread use of the allegory in Australian news accounts of national politics at that time. However, the gender war label continued to circulate well after the speech, appearing in news stories until Gillard's removal from office.

I situated my exploration of the gender war metaphor within critical discourse analysis (CDA) because "relations of power within discourses are typically condensed and expressed in authorized metaphors" (Carver and Pikalo 2008, 4). I also used techniques associated with critical metaphor analysis (CMA), as this approach determines what is emphasized, blurred, or ignored when meanings from the source domain of the metaphor (in this case, warfare) are transferred to the target domain (gender) (Cammaerts 2012, 232). CDA supplements CMA's focus on the linguistic elements of metaphor by providing an account of the ways in which discourses reproduce and reinforce cultural understandings about power and dominance (Fairclough 2001; van Dijk 
1993, 2008). As such, CDA "seeks to explore how specific discourses reproduce or transform relations of power as well as relations of meaning" (Mottier 2008, 189; emphasis mine). I drew primarily upon feminist critical discourse analysis, which focuses on the (re)production of gendered power relations (Lazar 2005, 11).

The news texts were analyzed through a three-stage qualitative data analysis process (Bryman, Teevan, and Bell 2009, 259). I began by carefully reading through the articles several times to get a sense of the literal and implied meanings conveyed by the uses of the gender war metaphor. In the second stage, I assessed the discursive impact of the metaphor, looking in particular at how it created mini narratives that reflected gendered understandings of power (Mottier 2008, 192). The entire inventory of gender war(s) metaphors was reexamined in the third stage of the data analysis process to ensure that the analysis was complete, and any incongruities were noted and explained.

\section{THE POLITICAL AND DISCURSIVE CONTEXT OF THE AUSTRALIAN “GENDER WARS”}

Australia has a Westminster-style bicameral parliamentary system. Executive power is located in the Australian House of Representatives, which is elected every three years via an alternative vote system. While minor parties like the Greens find modest electoral success, only two parties compete to form the government, the center-left Australian Labor Party (ALP) and the conservative-leaning permanent coalition between the Liberal Party of Australia and the National Party, collectively known as the Coalition. After a long period in office, the Coalition was defeated in 2007 by the ALP under the leadership of Kevin Rudd. Rudd appointed Julia Gillard, a popular and skillful parliamentarian first elected in 1998, to serve as his deputy prime minister. When the Labor party became increasingly dissatisfied with Rudd's leadership style and more and more worried about its reelection prospects, moves were made to unseat him. As a result, on June 23 2010, Gillard ascended to the prime minister's office through a process called a leadership "spill" or "coup"; a vote by members of the parliamentary party to replace the incumbent with a challenger. Gillard's victory was hailed as a "staggering and historic day" in Australian politics and celebrated as a major breakthrough for women (Trimble 2013, 10), but her rise was also 
reviled by those who accused her of disloyalty and treachery for overthrowing a sitting prime minister (Hall and Donaghue 2013, 638).

Gillard quickly called an election for late August 2010, hoping to consolidate her leadership with an election win. Instead the vote produced a tie between Gillard's Labor party and the opposition Coalition (Liberal and National parties). With the support of the Green Party and three Independents, Gillard was able to form a minority government but was dogged by controversies over unpopular policies and continuously confronted with internal challenges to her leadership from the man she had deposed. As documented by Australian journalist Kerry Walsh (2013), the Rudd forces made many clandestine attempts to undermine Gillard and mounted explicit, but unsuccessful, challenges to her leadership in February 2012 and March 2013. Eventually, with Labor's support dropping and an election looming, Rudd mobilized enough support to defeat Gillard in a leadership ballot held on June 26, 2013.

Challenges to Gillard's leadership formed a crucial backdrop to the mobilization of the gender war(s) metaphor, as critics from the ideological right, including the Coalition parties comprising the official opposition, and Coalition-friendly media outlets, derided Gillard's character in a manner that often directly referenced her gender. Gillard's political ambition was characterized as unseemly and unduly brutal for a woman (Hall and Donaghue 2013, 638). Media reporting of the 2010 election campaign featured an "extraordinary level of scrutiny" of Gillard's personal life, especially her marital status (Sawer 2012, 257). Gillard's approach to governing was also disparaged, with popular radio commentator Alan Jones accusing Gillard and other powerful Australian women of "destroying the joint" (Sawer 2013, 113). Most disturbingly, Gillard was confronted with sexist and hateful attacks from anonymous critics, as a plethora of pornographic and degrading images of the prime minister circulated on web sites, e-mail, and social media (see Summers 2012, 2013; Johnson 2015, 304-305). The Australian feminist movement used social media to protest these characterizations of Gillard (see McLean and Maalsen 2013; Sawer 2013). Yet the news media were largely silent about the sexism directed at Gillard, even when opposition leader Tony Abbott was directly implicated. For instance, while delivering a speech to carbon tax protesters, Abbott stood in front of a banner reading "Ju-liar ... Bob Brown's bitch." A newspaper account of

3. "Ju-liar" was a widely used slur on Gillard's character. By adding the letter " $r$ " to the end of Gillard's first name, critics, notably radio "shock jock" Alan Jones, cast the PM as a liar. 
this incident reported that protest signs also likened Gillard to a witch by exclaiming "ditch the witch." 4 Both labels are hostile to women, and they strongly evoke "the myth of women's power as unnatural and threatening" (Anderson and Sheeler 2005, 29). As these examples illustrate, gender had become integral to public discourses about the prime minster well before she delivered her parliamentary speech on sexism and misogyny. ${ }^{5}$

As I detail below, the gender war metaphor emerged prior to Gillard's condemnation of Abbott for his sexist attitudes and behaviors, but the majority of its usages were published in reaction to this speech. As one newspaper article put it, the speech "did not launch the gender war but rather signaled its zenith." 6 It was clearly a pivotal event, key to understanding the discursive context within which the gender war(s) metaphor was produced, framed, and consumed by news audiences. In a formal sense, Gillard's speech was delivered in response to opposition leader Tony Abbott's motion of no confidence in the speaker of the house, Peter Slipper. ${ }^{7}$ After the media leaked controversial text messages written by Slipper, one of which made crude references to female genitalia, Abbott rose in the House to demand Slipper's resignation from the Speaker's position. By refusing to call for Slipper's removal, Abbott argued, Gillard was acting hypocritically because she was quick to decry sexism and misogyny except when it came to the actions of one of her own supporters (McLean and Maalsen 2013, 250). As McLean and Maalsen $(2013,250)$ note, "few commentators observe the strategic use of sexism and misogyny by Tony Abbott in his initial speech, preferring to focus on Gillard's response." Gillard's rebuttal accused Abbott of hypocrisy for decrying sexist and misogynist attitudes in Parliament while himself regularly expressing such attitudes in public. ${ }^{8}$ Opening with the words "I will not be lectured about sexism and misogyny by this man. I will not," the prime minister gave several examples of statements by Abbott that indicated he held essentialist views about gender roles and

4. Michelle Grattan, "Election Game Plan 101: How to be a Hit with the Opposite Sex," The Sydney Morning Herald, December 22, 2012.

5. The full text of Gillard's speech can be accessed from the Sydney Morning Herald (www.smh.com), which published it on October 19, 2012.

6. Chris Kenny, “Abbott's Big Fight Back," The Australian, January 8, 2013.

7. Although the opposition's motion was narrowly defeated in the House, Slipper was convinced to resign from the speaker's position.

8. "Transcript of Julia Gillard's Speech," The Sydney Morming Herald, October 10, 2012. www.smh. com (accessed February 19, 2014). 
viewed women's lack of power as socially appropriate. ${ }^{9,10}$ Gillard's address also referenced Abbott's admonition that she should "make an honest woman of herself," 11 and it drew attention to his implied endorsement of those who called her a "witch" or "bitch" in public protests. ${ }^{12}$

\section{JULIA GILLARD, THE PRESS, AND THE GENDER WARS METAPHOR}

The gender war metaphor first appeared in newspaper coverage almost a month prior to Gillard's parliamentary speech, in response to the Labor party's critiques of opposition leader Tony Abbott's views on women's social equality claims. Four articles published in The Australian described Labor's strategy as a "concerted, inflammatory and calculated gender war campaign" in the form of a "frontal assault" on Abbott's character. ${ }^{13}$ This "battle" was said to target Abbott by "encouraging the view that Abbott is a misogynist." 14 As one headline put it, "Demonization of Abbott is Labor's New Game Plan."15 The Australian's political commentators alleged the "attacks" were carried out by Labor's senior cabinet ministers, mostly women, and trivialized them with the label "handbag hit-squad." 16 Labor's strategy was characterized as "offensive and false,"17 "farcical," and "inflammatory."18 One columnist maintained that the "war" on Abbott defied the common sense of the Australian public. ${ }^{19}$ In short, Labor was charged with launching an unprovoked and unwarranted attack on Abbott, using gender as a diversion from the Labor government's inability to gain traction in the polls. By deriding Gillard and Labor for using gender as an instrument of political warfare, newspaper columnists began the

9. Ibid.

10. For instance, Abbott said, "If it's true ... that men have more power generally speaking than women, is that a bad thing?" and "What if men are, by physiology or temperament, more adapted to exercise authority or to issue command?"

11. This was a reference to Gillard's marital status, as she is not legally married to her partner.

12. "Transcript of Julia Gillard's Speech," The Sydney Morning Herald.

13. Paul Kelly, "Hypocrisy Rules but Both Sides of Politics are Courting Danger," The Australian, October 3, 2012.

14. Ibid.

15. Paul Kelly, "Demonisation of Abbott is Labor's New Game Plan," The Australian, September 15, 2012.

16. Kelly, "Hypocrisy Rules," The Australian.

17. Chris Kenny, "Labor's British Import Brought the 'Problem with Women' Spin in His Baggage,"

The Australian, October 6, 2012.

18. Kelly, "Hypocrisy Rules," The Australian.

19. Kelly, "Demonisation of Abbott," The Australian. 
process of positioning gender inequality issues as an inappropriate subject of political contestation.

Gillard's October 9, 2012, parliamentary oration on sexism and misogyny was widely characterized by the press as a deliberate and calculated move designed to persist with, and indeed to intensify, Labor's rhetorical "strike" on Abbott. According to The Australian, the "Prime Minister continued her gender war against Tony Abbott." 20 The emotive and intense lexicon of warfare worked to frame Gillard's words as an extreme and unusual form of aggression against a political opponent. Newspaper coverage was replete with violent words and phrases, as Gillard's speech was labeled "vicious," "virulent," an "explosive attack," a "tirade," a "vitriolic" and "shrill attack," a "sexism crusade," a "gender salvo," and a "war on misogyny." 21 With few exceptions, reporters and columnists alike expressed indignation that the prime minister would persecute her political opponent in this manner. The speech was termed an "attempt to destroy Abbott instead of concentrating on governing." 22 Once again, allegations of disingenuousness and hypocrisy came into play. As one article claimed, the "nation's first female Prime Minister deliberately escalated the so-called gender war in order to defend a discredited Speaker."23

The trope of the unjust war dominated the coverage. Gillard's criticisms of Abbott for his sexist statements and views were judged "unfounded," 24 "implausible," and "farcical," 25 a "barrage of confected outrage" 26 designed to stoke a dangerous and "artificial gender war." ${ }^{27}$ In these characterizations of Gillard's speech as an unwarranted declaration of war against Abbott, gender was constituted as a weapon of combat and as a form of defensive armor. Deputy opposition leader Julie Bishop stated

20. John Ferguson and Patricia Karvelas, "PM 'Lets Women Down on Pay,"” The Australian, October $11,2012$.

21. The quotations are from the following, respectively: "Labor Now Moves Forward from Gender Wars Mistake," The Australian, October 15, 2012; Gabrielle Chan, "Shades of Outrage in Parliament's Sordid Story," The Australian, October 10, 2012; Grattan, "Election Game Plan 101"; Kelly, "Demonisation of Abbott"; Kenny, "Labor's British Import"; Kenny, "Early Poll is Labor's Best Hope of Saving the Brand," The Australian, October 27, 2012; Rick Morton and Mark Schliebs, "Men Retreat to Bunker over PM’s Gender Salvo," The Australian, June 18, 2013.

22. Dennis Shanahan, "Labor Continues with Strategy of Delusion," The Australian, October 11, 2012.

23. "The PM, the Speaker, his Texts and Their Misogyny," The Australian, October, 10, 2012.

24. Christopher Pearson, "Labor Living on Borrowed Time," The Australian, December, 15, 2012.

25. Paul Kelly, "Misogyny Tactic will Backfire," The Australian, October, 13, 2012.

26. Janet Albrechtsen, "Gender Wars Can't Help the Labor Cause Any More than a Quota PM," The Australian, June 5, 2013.

27. Christine Jackman, "Dangers of an Artificial Gender War," The Australian, January 12, 2013. 
that "the PM uses gender as a shield against criticism and she's using these vile claims of sexism and misogyny as a sword against her critics." 28 Comments such as "girls, girls, girls. Put down your gender guns," 29 "a female PM recklessly and ruthlessly uses gender as a weapon," 30 and "Gillard started a gender war and has used her sex to belittle Tony Abbott and other critics" 31 cast gender as an instrument of political aggression. Raising the issue of gender was itself deemed a cynical and desperate defensive maneuver designed to protect the prime minister from what news commentators saw as appropriate censure from political opponents. $^{32}$

In the speech, Gillard drew attention to sexist and hateful evaluations of her integrity and character. Yet only one column suggested Gillard's words were a reaction not merely to Abbott's charge that she was condoning sexism by defending Slipper, but also to the hurtful and often pornographic representations she herself had endured in silence over the years. The Age's Katharine Murphy felt the prime minister's speech was spontaneous, "a blow-up of pure frustration: volcanic and howling in intensity because the prelude to the explosion is a long period of not saying. What woman can't relate to that? We've all been there, not saying, broiling about the injustice of not saying." 33 But this interpretation was anomalous. That Gillard had been the subject of sexist commentary from political opponents, including Abbott, was rarely acknowledged in the articles invoking the gender war metaphor. ${ }^{34}$ Moreover, when sexism directed at Gillard was mentioned, Gillard was censured for raising the issue. The perpetrators of sexist and sexually explicit commentary against Gillard were, according to one columnist, merely "'misogynists and cranks' who anonymously libeled and reviled the Prime Minister online." 35 In other words, this sort of sexism could not be taken seriously because it takes place in the marginal and

28. Stephanie Peatling and Farrah Tomazin, "Wong Calls for Truce in Gender War," The Sunday Age, October 14, 2012, emphasis mine.

29. Albrechtsen, "Gender Wars Can't Help the Labor Cause," The Australian.

30. Janet Albrechtsen, "PM's Fake Feminism is Man Made," The Australian, January 23, 2013.

31. Dennis Shanahan, "For Labor's Sake, PM Must Drop the Words that Divide," The Australian, March 23, 2013.

32. For example, "The PM, the Speaker, his Texts and their Misogyny," The Australian; Joe Kelly, "Warning to PM on Sexism Crusade," The Australian, October 15, 2013.

33. Katharine Murphy, "Life Moments in the Kitchen of the Great House," The Age, October 14, 2012, emphasis mine.

34. Grattan, "Election Game Plan 101"; "Warning to PM on Sexism Crusade," The Australian.

35. Dennis Shanahan, "PM's Gender War Ends in Spectacular Self-Wedge," The Australian, October 12, 2012. 
anonymous spaces of unofficial political discourses. Another reporter conceded that "some of the ire directed at Gillard has been sexist, even offensively so. Yet it has been her choice to shift this unseemly fringe of political life to centre stage." 36 According to this narrative, by refusing to remain silent about sexism Gillard chose to move an unpalatable subject from places where it is allegedly private and/or harmless into public sites of mainstream political discourse, where it does not belong.

The prime minister's willingness to invoke her own gendered social location was also read as profoundly damaging to women, the feminist cause, and to political dialogue more generally. ${ }^{37}$ Gillard's speech was characterized as "an affront to women who have suffered harm from sexism and misogyny." 38 Also, it was seen as antifeminist: by "making deliberately empty allegations of misogyny against Tony Abbott, the gender-card-waving PM rates poorly as a feminist role model." 39 The press asserted that Gillard's words and actions demeaned political debate and deflected attention from more important topics. For instance, the "gender wars have poisoned the political discourse and polarized debate" and thus "must be set aside if Julia Gillard is to govern in the national interest." 40 As another wrote, the "quality of the political debate has become risible. Instead of discussing the government's priority areas or debating a serious economic reform agenda, we are reduced to gender wars." ${ }^{1}$ These assessments characterized discussions about gender inequality and sexism as inherently polarizing and destructive, as opposed to arguments about other contentious political issues, which, by implication, make valid contributions to public debates.

The gender war(s) metaphor continued to circulate in press coverage for eight months after Gillard's parliamentary speech and was invigorated in June 2013 in response to two events. The first was the prime minister's speech to a Labor Party fund-raising group called Women for Gillard. According to media accounts, Gillard said a government dominated by "men in blue ties" would banish women from the center of political

36. Chris Kenny, "Gillard's Hypocrisy Stripped Bare by her Defence of Demonstrable Misogyny," The Australian, October 13, 2012, emphasis mine.

37. By characterizing the so-called "gender wars" in this manner, the press reinforced radio personality Alan Jones's admonition that Gillard and other powerful women were "destroying" Australia.

38. Niki Savva, "Gillard Could Learn from Obama that it's about Winning not Whining," The Australian, November 8, 2012, emphasis mine.

39. Albrechtsen, "PM's Fake Feminism is Man Made," The Australian.

40. Shanahan, "For Labor's Sake," The Australian, emphasis mine.

41. Chris Kenny, "Early Poll is Labor's Best Hope of Saving the Brand," The Australian, October 27, 2012, emphasis mine. 
decision making and make abortion "the political plaything of men who think they know better." 42 The day after this speech was delivered the government released information about a satirical menu created for a Coalition fundraiser that "included a dish described as "Julia Gillard Kentucky Fried Quail - Small Breasts, Huge Thighs \& a Big Red Box." 43 Labor argued the menu illustrated the pattern of sexism directed at Gillard by political opponents. ${ }^{44}$ These events were linked in media commentary and described as "Julia Gillard's return to the gender trenches." ${ }^{5}$ Gillard was alleged to have "reignited the gender wars." 46 Dramatic headlines such as "PM Fires Abortion Salvo in Gender War" illustrated the extent to which the metaphor structured press coverage of Gillard's speech acts in the waning days of her political career. ${ }^{47}$

With the notable exception of Anne Summers' column, titled "It's Gillard's Right to Fight Back,"48 news reports once again strongly rebuked the prime minister for discussing sexism in public life. Gillard's "men in blue ties" speech was deemed a "cynical ploy"49 and an "unfounded attack on blue ties as symbolic of institutionalized sexism." 50 An editorial in The Australian (2013) titled "Julia Gillard's Clumsy and Manipulative Gender Wars" cast the speech as "an act of desperation that ill-judged its intended audience." 51

Invocations of the metaphor once again positioned gender as a site of political struggle, with Gillard attacking men and sexism in an effort to win support, especially from women, in a last-ditch effort to salvage her political career in the face of a mounting leadership challenge from Kevin Rudd, the man she had deposed just three years earlier. Reporters quickly and unequivocally pronounced the campaign an abject failure, with headlines like "Gender War Misfires for PM" 52 and assertions that

42. Mark Kenny, "PM Targets 'Men in Blue Ties," The Sydney Morning Herald, June 12, 2013.

43. Andrew Fraser and Sid Maher, "Menu Offensive is Still Only Half-Baked," The Australian, June 14, 2013.

44. Rick Morton, “ABC Slow to Digest Story's Course," The Australian, June 14, 2013.

45. Rick Morton and Mark Schliebs, "Men Retreat to Bunker over PM's Gender Salvo," The Australian, June 18, 2013.

46. Fraser and Maher, "Menu Offensive is Still Only Half-Baked," The Australian.

47. Sid Maher, "PM Fires Abortion Salvo in Gender War," The Australian, June 12, 2013.

48. Anne Summers, "It's Gillard's Right to Fight Back," The Sydney Morming Herald, June 14, 2013.

49. Peter Hartcher, "PM's Cynical Ploy Fails to Win Voters," The Sydney Morning Herald, June 17, 2013.

50. Michael Loziol, "Big Issues Ignored in Papier Maché Policy Showdown," The Sydney Morning Herald, June 14, 2013.

51. June 13, 2013.

52. Dennis Shanahan, "Gender War Misfires for PM," The Australian, June 25, 2013. 
"Julia Gillard's retreat to the gender trenches backfired savagely." 53 The trope of the failed war percolated through these texts, prefiguring the events to come. Less than two weeks later, Rudd and his supporters toppled Gillard from the Labor party leadership and the prime minister's post.

\section{DISCUSSION: METAPHOR AND POLITICAL NARRATIVE}

By controlling the spaces within which news about politics is filtered and framed for public consumption, the news media have a significant role to play in structuring political narratives. News stories about the so-called gender wars were highly mediated political discourses, as the gender war metaphor was largely a creation of the Australian press. In $94 \%$ of the usages of the metaphor in 59 news stories, journalists and columnists alike wrote the metaphor into their stories without attribution. While opposition leader Tony Abbott gave one statement in which he used the allegory of the gender wars, he did not do so until late November 2012, almost two months after his parliamentary exchange with Gillard. By this time the metaphor was commonplace in news accounts of the prime minister's speech. One opinion-leading newspaper in particular, The Australian, which is widely known for its pro-Coalition stance (Young 2011, 243, 249), introduced and persistently disseminated the metaphor in its editorials and columns. The constant invocation of the gender war(s) label by The Australian reveals a particular approach to defining "politics." Metaphors are designed to emphasize some perspectives while hiding or delegitimizing others. Used in the Australian context to condemn the prime minister's actions, the gender war(s) metaphor fostered a particular narrative about political strategies and the appropriate rules of engagement for political debate. I argue that the gender war metaphor located Gillard's speech acts outside the boundaries of legitimate political discourses, thus illustrating the gendered nature of mediated power relations.

By associating the source domain of the metaphor with a plethora of battle words and violent images, the metaphor positioned gender as a weapon of war and Gillard as the aggressor. Words such as battles, fights, campaigns, crusades, strikes, offensives, bunkers, trenches, and front lines peppered the news coverage, and Gillard and members of her government were said to take up arms, attack, launch salvos, erupt

53. Morton and Schliebs, "Men Retreat to Bunker," The Australian. 
firestorms, deploy hit teams, and even slay opponents. However, these lexical choices are not, in and of themselves, surprising. After all, war metaphors are so prevalent in mediated representations of politics that the literal meaning of the metaphor - politics is conflict - has become completely conventionalized (Charteris-Black 2011, 3). That war metaphors are regularly used to characterize a wide range of "civilian social practices as militarized spaces" signals "the entry of war mentality into the realm of the general "commonsense" (Lazar 2009, 209). Because the language of combat and belligerence is normalized in media discourses about politics, political actors are not blamed for planning, strategizing, or enacting rhetorical violence. It is simply taken for granted that they will figuratively fight each other to the death on the political battlefield. This form of political aggression is typically lauded as evidence of power, strength, and the will to succeed (Charteris-Black 2011, 3). Indeed, mediated military metaphors express approval of ruthlessness and fearlessness in political competitions.

In contrast, Gillard's words and actions were condemned. The Australian press vociferously and almost universally disparaged Gillard's reproach to Abbott for his sexist attitudes and derided her attempt to discuss the sex bias she had experienced in her role as the most powerful political actor in Australia. In fact, the gender war metaphor was used to characterize Gillard and her party as the aggressors, and Abbott and other critics of the government as the innocent victims of Labor's ongoing and increasingly virulent "attacks." Moreover, Gillard's intentions were represented as deceptive, cynical, and hypocritical, her actions judged dangerous, ruthless, vicious, and vitriolic. Hyperbolic terms such as inflammatory, destructive, offensive, poisonous, and polarizing punctuated the deleterious impact of the so-called gender wars. Gillard's "wars" were said to directly and unfairly wound political opponents and cause collateral damage to political discourse and to society as a whole. ${ }^{54}$ By labeling Gillard and her party's actions as a series of injurious gender wars, the media rendered contestations of sexism and gender inequality a destructive and dishonorable approach to political engagement.

The widespread, indeed ubiquitous, use of combat metaphors to describe political behavior conveys approval for certain political tactics and performances. Underlying these metaphors is the understanding that there are norms guiding "just" political warfare. In Gillard's case, the act of drawing attention to sexism was metaphorically constructed as unjust - a

54. The Australian, "Gender Wars No Substitute for Constructive Policies," October 8, 2012. 
bizarre twist of logic. When used in concert with the gender war construct, adjectives such as artificial, phony, farcical, ridiculous, inappropriate, desperate, clumsy, manipulative, and disastrous represented gender as an inauthentic and fundamentally inappropriate site of political struggle. The gender war metaphor thus performed ideological work by containing and constraining discussion of sexism and gender inequality in Australian political life. As Falk $(2013,194)$ observes, metaphors "can help society to highlight what it wants to believe and avoid what it does not wish to face." That Gillard was rebuked for refusing to stay silent about sexism and blamed for bringing the issue to the attention of the public illustrates this point. One commentator came right out and said that society will condemn those who raise issues of sexism: "on race and gender - we are aware of injustice but the accusatory finger is unwelcome." 55 News accounts represented Gillard's challenge to the gender order as an unjust form of political contestation, thus precluding the opportunity to examine gendered power relations and political inequality as real problems in the political environment.

Metaphors are powerful instruments of discourse because they tap into commonly held understandings about society and politics. In fact, "one of the main rhetorical purposes of metaphor is to contribute to developing political myths" (Charteris-Black 2011, 38). Gillard's decision to speak out about the sexism she had encountered as prime minister violated deeply held and highly valued myths about Australian society, in particular the myth of the "fair go." In Australian culture, the perception that everyone who works hard enough will have an equal chance to succeed is widely held and frequently invoked in political party and government documents (e.g., Australia 2007, 6). This value was publicly challenged when Gillard, speaking from her own experience, exposed unfair treatment and inequality. Very simply, Gillard pointed out that she was not having a "fair go." As Johnson (2015, 310) observes, "it is an immensely powerful moment to have a prime minister stand up and say she had been discriminated against." The gender war metaphor worked to undermine Gillard's critique and reestablish the myths of equal opportunity and fair play. In fact, one columnist expressed incredulity in response to the prime minister's examples of sexism: "Gillard's career has not suffered because of her sex and it's demeaning to pretend it has." 56 The fact that a woman had 
ascended to the top political job was, in and of itself, seen as sufficient to support the myth of gender equality as integral to every Australian's chance at a "fair go."

\section{CONCLUSIONS}

I have illustrated that the Australian press, particularly the pro-Coalition paper, The Australian, used the gender war metaphor to portray Gillard and her party as aggressively and irrationally attacking a political opponent, in the process inflicting collateral damage to women, the feminist cause, and the national interest. In addition to delegitimizing Gillard via the trope of the unruly woman (Anderson and Sheeler 2005), the gender war metaphor both revealed and reinforced inequitable power relations. Metaphors "hide relations of power and dominance" (Falk 2013, 204) by asserting particular positions and arguments while masking or delegitimizing others. By scripting the narrative of "Julia, the Feminist Warrior, slaying misogynists whenever they cross her path"57 and saying that she was "exploiting her gender as a political weapon," 58 news reports maintained that Gillard's position as prime minister, coupled with her gender, allowed her to wage an unfair war against her opponent. Obscured in this interpretation was the gender-based unfairness Gillard had experienced as prime minister. Also elided was Abbott's role in the "battle" over sexism and misogyny. Most of the coverage ignored Abbott's complicity, and the few articles acknowledging his sexist characterizations of Gillard declared the prime minister out of line for charging her opponent with sexism and especially for using the word misogynist. The chauvinistic and at times overtly hostile comments Abbott directed toward Gillard were thus occluded by the outrage directed at Gillard for raising the issue.

While the metaphorical construct of the gender-based war seemed to confer political agency upon Gillard, characterizing her as powerful and commanding, the entailments of the metaphor rendered the prime minister discursively powerless. Indeed, several attempts to draw attention to the ways in which Gillard had been a target of sexist criticism by the opposition were described as inauthentic and hypocritical. Nor could Gillard contest the criticism directed at her from political opponents and

57. Janet Albrechtson, "The Perils of the Prime Minister's Feminist Fantasies," The Australian, November 7, 2012.

58. Grattan, "Election Game Plan 101," The Sydney Morning Herald. 
the media, as the gender war was presented as an unseemly spectacle, unworthy of any leader, never mind the nation's first woman prime minister. By disciplining Gillard for challenging important national myths and violating the unspoken norms of "just" political combat, the gender war narrative precluded discussions about gender bias and discrimination against women. Falk $(2013$, 202) showed how the playing-the-gender-card metaphor performed a similar (though less overtly condemnatory) form of silencing in the U.S. context when Hillary Clinton sought the Democratic presidential nomination in 2008. In Australia, the gender war metaphor vilified a government leader for daring to speak in public about the sexism she had encountered during her term as the most powerful political figure in the country. The denunciation inherent in the use of the gender war metaphor effectively shuts down public conversations about gender by rebuking those who raise the issue.

So, why does it matter now that Julia Gillard is no longer in office and the Australian media have dropped the lexicon of gender warfare in descriptions of "battles" between male politicians? The mediated reaction to Gillard's mobilization of gender in public discourses provides a stern warning to elite women politicians who dare to challenge dominant cultural norms by speaking publicly about sexism in political life. With the metaphor now in wide circulation in reaction to Gillard's political leadership, the trope of the woman-led gender war could easily be resurrected and applied to leadership candidates such as Hillary Clinton, as she seeks the Democratic presidential nomination in 2016. In addition to shaping the gender strategies of future women political leaders, who will undoubtedly be wary of saying anything at all about women's political inequality, the metaphor is likely to regulate the very nature of gender-related political contestations. As Julia Gillard's experience shows, the gender war metaphor operates at a discursive level to subtract gendered power relations from normative understandings of the political.

Linda Trimble is Professor of Political Science at the University of Alberta, Edmonton, Alberta, Canada: ltrimble@ualberta.ca 


\section{REFERENCES}

Australian Broadcasting Corporation (ABC). 2012. "The Speech that Burst the Press Gallery's Bubble." Media Watch, Episode 37, October 15. http://www.abc.net.au/ mediawatch/transcripts/s3611115.htm (accessed February 19, 2014).

Ahrens, Kathleen. 2009. “Analysing Conceptual Metaphors in Political Language.” In Politics, Gender and Conceptual Metaphors, ed. Kathleen Ahrens. Basingstoke: Palgrave Macmillan, 1-5.

Anderson, Karrin Vasby, and Kristina Horn Sheeler. 2005. Governing Codes: Gender, Metaphor and Political Identity. Lanham: Lexington Books.

Australia. 2007. "Life in Australia." Government of Australia, Department of Immigration and Citizenship. www.immi.gov.au (accessed March 30, 2014).

Blankenship, Jane. 1996. "The Search for the 1972 Democratic Party Nomination: A Metaphorical Perspective." In Rhetoric and Communication, ed. Jane Blankenship and Hermann Stelzner. Urbana: University of Illinois: 236-60.

Blankenship, Jane, and Jong Guen Kang. 1991. "The 1984 Presidential and Vice Presidential Debates: The Printed Press and 'Construction' by Metaphor." Presidential Studies Quarterly 41 (2): 307-18.

Bryman, Alan, James J. Teevan, and Edward Bell. 2009. Social Research Methods, 2nd Canadian ed. Don Mills: Oxford University Press.

Cammaerts, Bart. 2012. "The Strategic Use of Metaphors by Political and Media Elites: The 2007-11 Belgian Constitutional Crisis." International Journal of Media \& Cultural Politics 8 (2-3): 229-49.

Carver, Terrell, and Jernij Pikalo. 2008. "Editor's Introduction." In Political Language and Metaphor, ed. Terrell Carver and Jernej Pikalo. London and New York: Routledge, $1-11$.

Castells, Manuel. 1996. The Rise of the Network Society. Oxford: Basil Blackwell.

Charteris-Black, Jonathan. 2011. Politicians and Rhetoric: The Persuasive Power of Metaphor, 2nd ed. Basingstoke: Palgrave MacMillan.

Fairclough, Norman. 2001. Language and Power, 2nd ed. New York: Pearson Education.

Falk, Erika. 2013. "Clinton and the Playing-the-Gender-Card Metaphor in Campaign News." Feminist Media Studies 13 (2): 192-207.

Faludi, Susan. 1992. Backlash: The Undeclared War Against American Women. New York: Anchor Books.

Gidengil, Elizabeth, and Joanna Everitt. 1999. "Metaphors and Misrepresentation: Gendered Mediation in News Coverage of the 1993 Canadian Leaders' Debates." International Journal of Press/Politics 4 (1): 48-65.

Hall, Lauren J., and Ngaire Donaghue. 2013. “Nice Girls Don't Carry Knives': Constructions of Ambition in Media Coverage of Australia's First Female Prime Minister." British Journal of Social Psychology 52 (4): 631-37.

Howe, Nicholas. 1988. "Metaphor in Contemporary American Political Discourse." Metaphor and Symbolic Activity 3 (2): 87-104.

Johnson, Carol. 2015. "Playing the Gender Card: The Uses and Abuses of Gender in Australian Politics." Politics \& Gender 11 (2): 291-319.

Koller, Veronika. 2004. "Businesswomen and War Metaphors: 'Possessive, Jealous and Pugnacious'?” Journal of Sociolinguistics 8 (1): 3-22.

Koller, Veronika, and Elena Semino. 2009. "Metaphor, Politics and Gender: A Case Study from Germany." In Politics, Gender and Conceptual Metaphors, ed. Kathleen Ahrens. Basingstoke: Palgrave Macmillan: 9-35

Lakoff, George, and Mark Johnson. 2003. Metaphors We Live By. Chicago and London: University of Chicago Press. 
Lazar, Michelle M. 2005. "Politicizing Gender in Discourse: Feminist Critical Discourse Analysis as Political Perspective and Praxis." In Feminist Critical Discourse Analysis: Gender, Power and Ideology in Discourse, ed. Michelle M. Lazar. New York: Palgrave MacMillan, 1-28.

_ 2009. "Gender, War and Body Politics: A Critical Multimodal Analysis of Metaphor in Advertising. In Politics, Gender and Conceptual Metaphors, ed. Kathleen Ahrens. Basingstoke: Palgrave Macmillan: 209-34.

Lester, Amelia. 2012. “Ladylike: Julia Gillard's Misogyny Speech.” The New Yorker, October 9. http://www.newyorker.com/news/news-desk/ladylike-julia-gillards-misogynyspeech (accessed February 19, 2014).

Lim, Elvin T. 2009. "Gendered Metaphors of Women in Power: the Case of Hillary Clinton as Madonna, Unruly Woman, Bitch and Witch." In Politics, Gender and Conceptual Metaphors, ed. Kathleen Ahrens. Basingstoke: Palgrave Macmillan: 254-69.

McLean, Jessica, and Sophia Maalsen. 2013. "Destroying the Joint and Dying of Shame?" Geographical Research 51 (3): 243-56.

Melich, Tanya. 1996. The Republican War Against Women. New York: Bantam.

Mottier, Véronique. 2008. "Metaphors, Mini-Narratives and Foucauldian Discourse Theory." In Political Language and Metaphor, ed. Terrell Carver and Jernej Pikalo. London and New York: Routledge, 182-94.

Nielsen, Rasmus Kleis, and Kim Chritina Schroder. 2014. "The Relative Importance of Social Media for Accessing, Finding, and Engaging with News." Digital Journalism 2 (4): 472-89.

Parry-Giles, Shawn J. 2014. Hillary Clinton in the News: Gender and Authenticity in American Politics. Urbana: University of Illinois Press.

Sawer, Marian. 2012. "Managing Gender: The 2010 General Election.” In Julia 2012: The Caretaker Election, ed. Marian Simms and John Wanna. Canberra: ANU E Press: 251-66.

—. 2013. "Misogyny and Misrepresentation: Women in Australian Parliaments." Political Science 65 (1): 105-17.

Summers, Anne. 2012. "Her Rights at Work: The Political Persecution of Australia's First Female Prime Minster." Human Rights and Social Justice Lecture, University of Newcastle, August 2012. http://annesummers.com.au (accessed February 26, 2016).

_ . 2013. "Her Rights at Work: The Political Persecution of Australia's First Female Prime Minister." The Economic and Labour Relations Review 23 (4): 115-26.

Trimble, Linda. 2013. "Melodrama and Gendered Mediation: Television Coverage of Women's Leadership 'Coups' in New Zealand and Australia." Feminist Media Studies 14 (4): $663-78$.

Trimble, Linda, and Natasja Treiberg. 2010. “Either Way, There's Going to be a Man in Charge': Media Representations of New Zealand Prime Minister Helen Clark.” In Cracking the Highest Glass Ceiling: A Global Comparison of Women's Campaigns for Executive Office, ed. Rainbow Murray. Santa Barbara, CA, and Oxford: Praeger, 11636.

Van Dijk, Teun. 1993. "Principles of Critical Discourse Analysis." Discourse and Society 4 (2): $241-83$.

Walsh, Kerry-Anne. 2013. The Stalking of Julia Gillard. Crows Nest NSW: Allen \& Unwin.

Young, Sally. 2011. How Australia Decides: Election Reporting \& The Media. Melbourne: Cambridge University Press.

YouTube. 2012. "Gillard Labels Abbott a Misogynist," ABC News Australia, October 9. https://www.youtube.com/watch?v=ihd7ofrwQX0 (accessed February 19, 2014). 